\title{
Trends in the Development of Science Fiction Literature in Taiwan
}

\author{
David Uher \\ Department of Asian Studies, Philosophical Faculty, Palacký University in Olomouc, Křižkovského 8, 77180 Olomouc, \\ Czech Republic
}

\section{TRENDY VE VÝVOJI SCI-FI LITERATURY NA TAIWANU}

\begin{abstract}
ABSTRAKT Literární kritika vědeckou fantastiku většinou ostentativně přehližźí, přitom H. G. Wellse, Isaaca Asimova, Roberta A. Heinleina, Raye Bradburyho či Arthura C. Clarka aj. lze jen stěží označit za bezvýznamné pisálky ... Na konci šedesátých let minulého století, konkrétně v roce 1968, publikovala Zhang Xiaofeng 張曉風v deníku Zhongguo Shibao 《中國時報》China Times povídku Panduna 《潘渡娜》Pandora. Ta je považována za první dílo taiwanské vědecko-fantastické prózy. V sedmdesátých a osmdesátých letech 20. století pak vědecko-fantastická literatura na Taiwanu zaznamenala bouřlivý rozvoj: byla uveřejňována v denících a časopisech, publikována ve vydavatelstvích, byly zakládány vědecko-fantastické časopisy, vyhlašovány první literární soutěže pro autory vědecké fantastiky a udělovány první ceny. Současně vznikaly první kritické práce a objevili se i první významní autoři vědecko-fantastické literatury, například Huang Hai 黄海 či Zhang Xiguo 張 系國aj. Dvacet let vývoje taiwanské vědecké fantastiky ukončila na počátku devadesátých let 20. století vlna amerických vědecko-fantastických filmů. Počátky, rozvoj a úpadek vědecko-fantastické literatury na Taiwanu je proto jako ukončený jev možno popsat i analyzovat. Její historie je téměř u konce, a tak můžeme nejen hodnotit její význam, ale zároveň ji i srovnat s vývojem nejvlivnější vědecko-fantastické literatury na světě - americké vědecké fantastiky. Popis vývoje a toto srovnání jsou hlavním záměrem tohoto př́spěvku.
\end{abstract}

KLÍČOVÁ SLOVA literární kritika; komparatistika; moderní taiwanská literatura; vědecko-fantastická literatura; Zhang Xiguo

\begin{abstract}
Science fiction literature is commonly disregarded by main stream literature. Gratuitously: e.g. H. G. Wells, Isaac Asimov, Robert A. Heinlein, Ray Bradbury and Arthur C. Clarke can hardly be insignificant scribblers ... In late 1960s, in 1968 to be precise, Zhongguo Shibao 《中國時報》China Times published Zhang Xiaofeng's 張曉風 novel Panduna 《潘渡娜》Pandora. It is regarded as the first example of Taiwanese science fiction prose ever written. In the 1970s and 1980s science fiction literature experienced the turbulent progress in Taiwan: sci-fi literature was published by newspapers, periodicals and publishing houses, sci-fi magazines were established, the first competitions for authors of science fiction literature were announced, the first prizes were awarded. In addition, the first critical works were written and sci-fi stars such as Huang Hai 黃海 and Zhang Xiguo 張系國 appeared. The twenty years of development of Taiwanese sci-fi came to a halt in the early 1990s with the boom of science fiction cinema. The beginning, development and decline of science fiction literature in Taiwan as a definite phenomenon can therefore be analysed and described. Its history is almost completed, thus we can not only elevate, but also compare her development with the most influential science fiction literature in the world: American science fiction. A description of the development and a comparison are the main purpose of this paper.
\end{abstract}

KEY WORDS criticism; comparative studies; modern Taiwanese literature; sci-fi literature; Zhang Xiguo

\section{DEFINITION}

Science fiction literature is a broad genre of fiction which often involves speculations based on current or future science or technology. Science fiction is largely based on writing in an entertaining and rational manner about alternative possibilities in settings which are contrary to known reality. These include: a setting in the future, in alternative time lines, or in a historical past that contradicts known facts regarding history or the archaeological record; a setting in outer space, 
on other worlds, or involving aliens; stories that contradict known or supposed laws of nature; stories that involve discovery or application of new scientific principles, such as time travel, or new technology, such as nanotechnology, fasterthan-light travel or robots, or of new and different political or social systems.

\section{GENRES}

Literary critics tend to place science fiction literary works into various categories - "genres": Hard science fiction is characterized by rigorous attention to accurate detail in the quantitative sciences, in particular physics, astrophysics, and chemistry. Arthur C. Clarke, for example, predicted a number of future developments accurately. Certain hard science fiction authors have also distinguished themselves as working scientists. Soft science fiction may describe works based on the social sciences such as psychology, economics, political science, sociology and anthropology. Ray Bradbury is an acknowledged master of this art. Related to Soft science fiction are the speculative fiction branches of utopian or satirical stories; Nineteen Eighty-Four, and City of Cats could be viewed as examples. Common themes in cyberpunk include advances in information technology, especially the Internet. Blade Runner is commonly accepted as a definitive example of the cyberpunk visual style. Time Travel stories were popularized by H. G. Well's novel The Time Machine. Alternate history stories are based on the premise that historical events might have turned out differently. Military science fiction is set in the context of conflicts between national, interplanetary, or interstellar armed forces; the primary viewpoint characters are usually soldiers. Heinlein's Starship Troopers is an early example ${ }^{1}$.

\section{HISTORY}

Science fiction has antecedents back in mythology, although precursors to science fiction as literature began to emerge from the 13th century to the 17th century in the Age of Reason with the development of science itself, Voltaire's Micromégas was one of the first, along with Jonathan Swift's Gulliver's Travels. Edgar Allan Poe later wrote a story about a flight to the moon. More examples appeared throughout the 19th century. Then with the dawn of new technologies such as electric-

\footnotetext{
1 The broader category of speculative fiction includes science fiction, fantasy and horror. Fantasy is closely associated with science fiction, although science fiction is the literature of things that might someday be possible, and fantasy is the literature of things that are inherently impossible, such as magic and mythology. Horror fiction is the literature of the unnatural and supernatural, with the aim of unsettling or frightening the reader. Many works of horror literature only incorporate science fiction elements: Mary Shelley's novel Frankenstein.
}

ity, the telegraph, and new forms of powered transportation, writers such as Jules Verne and Herbert George Wells created a body of work that became popular across broad crosssections of society. In the early 20th century, pulp magazines helped develop a new generation of mainly American science fiction writers, influenced by Hugo Gernback, the founder of Amazing Story magazine. In the late 1930s, John W. Campbell became editor of Astounding Science Fiction. Important writers during this period included Isaac Asimov, Robert A. Heinlein and Arthur C. Clarke. Campbell's tenure at Astounding Science Fiction is considered the beginning of the Golden Age of science fiction, characterized by hard science fiction stories celebrating scientific achievement and progress. In the 1960s and early 1970s, writers such as Frank Herbert, Samuel R. Delany and Roger Zelazny explored new trends, ideas, and writing styles. In the 1980s, cyberpunk authors turned away from the traditional optimism and support for progress of traditional science fiction. Star Wars helped spark a new interest in space opera, focusing more on story and character than on scientific accuracy. The television series Star Trek: the Next Generation began a torrent of new science fiction programs and was among the most highly acclaimed of the decade. Television shows and films created new interest in all the speculative genres in films, television, computer games, and books. Among the most respected awards for science fiction are the Hugo Award and the Nebula Award. Conventions are held in cities around the world, catering to a local, regional, national, or international membership. General-interest conventions cover all aspects of science fiction, while others focus on a particular interest. Most are organized by volunteers in non-profit groups, although most media-oriented events are organized by commercial promoters. The convention's activities are referred to as the "program", which may include panel discussions, readings, autograph sessions, costume masquerades, and other events. Science fiction societies, referred to as "clubs" except in formal contexts, form a year-round base of activities for science fiction fans. They may be associated with an ongoing science fiction convention, or have regular club meetings, or both. Most groups meet in libraries, schools and universities, community centres, pubs or restaurants, or the homes of individual members. Fandom has helped incubate related groups. The first science fiction fanzine, The Comet, was published in 1930.

\section{A HISTORY OF TAIWANESE SCIENCE FICTION}

1950s: The prehistory of Taiwanese science fiction literature began in the 1950s, but has been regarded as "a Desert of Science Fiction": with only American science fiction films being shown and San Xin 三信 San Xin Publishing House in Gaoxiong publishing Zhao Zifan's 趙滋藩 Feidie Zheng Kong 《飛碟征空》A UFO Attacks the Sky, Taikong Lixian Ji 《太空歷險記》Records of Adventure in Outer Spaces and Yueliangshang Kan Diqiu 《月亮上看地球》A View of Earth from the Moon. These are actually more pseudo-scientific 
works than actual science fiction literature. In the late 1950s the Hong Kong author Ni Kuang倪匡using the pseudonym Weisili衛斯理Wesley began to create his saga written as autobiography. His innumerable stories should be classified, however, as fantasy, not science fiction.

1960s: At the beginning of the 1960s Mofan Shaonian 《模範少年》Imitation of Youth magazine published translations of foreign science fiction literature in a fragmented fashion. The actual history of Taiwanese science fiction began in September 1968 when Zhongguo Shibao 《中國時 報》China Times issued Zhang Xiaofeng'張曉風short story Panduna 《潘渡娜》Pandora describing the unsuccessful creation of an artificial girl, a clone Pandora. Although Pandora is a beautiful girl whose appearance does not differ from a normal human girl, she has no "substance", no soul and therefore dies at the end. Of interest is the fact that the story shares certain characteristics with the above alreadymentioned Mary Wollstonecraft Shelley's Frankenstein. It is one of the first science fiction works in a European context, the author is also a woman and the topics are also very similar. It is more of a love story and psychological prose with a science fiction background, a reflection on the nature of humanity searching for the answer as to whether humans have the right to play the role of God and create other "human" beings? In October 1968 Zhang Xiguo張系國, a computer scientist with literary ambitions, published Chaoren Liezhuan 《超人列傳》A Biography of Superman in Chun Wenxue 《純文學》Pure Literature. A mere two months later, in December 1968, Huang Hai黃海, an author of social short stories at that time, began to publish Hang Xiang Wuya d Lucheng 《航向無涯的旅程》- a series of science fiction stories on travels through the universe in Zhonghua Ribao 《中華日 報》China Daily. Zhang Xiaofeng did not write all that many science fiction stories. Zhang Xiguo and Huang Hai, in particular, will be made mention of repeatedly in this paper. Their contribution to the creation and development of Taiwanese science fiction in terms of both the creative and theoretical aspects should not be underestimated along with their struggle for popularisation of science fiction in Taiwan. In May 1969 Yan Yuanshu顔元叔published Renlei Gongchengxue - jian Tan Chaoren Liezhuan yu Panduna 《人類工程學——兼談 「超人列傳」與「潘渡娜」》Human Engineering: on the Biography of Superman and Pandora in Daxue Zazhi 《大學 雜誌》University Journal. It is the first theoretical paper on Taiwanese science fiction literature ever recorded. In October 1969 Zhang Xiguo in Pure Literature published an article Beng Yue zhihou - jian Lun Kexue Huanxiang Xiaoshuo 《奔 月之後 一一兼論科學幻想小說》After Running to the Moon - On Science Fiction Prose and thus created a term, the Chinese name for science fiction. At the end of the 1960s Huang Hai decided to publish Yilingyilingyi Nian 《-O- $\mathrm{O}-$ 年》Year 10101. Although he was still seeking out a method of expression in the story, it was awarded the Juvenile Literature Prize by the National Society. 1970s: Thanks to the efforts of the science fiction enthusiasts Zhang Xiguo, Huang Hai and Lü Yingzhong, Taiwanese publishing houses began to release foreign science fiction literature. Although the American writers, e. g. Isaac Asimov, Ray Bradbury and Arthur C. Clarke, etc. prevailed, translations of European and surprisingly Soviet science fiction authors were also introduced to Taiwanese readers ${ }^{2}$. In December 1972 Huang Hai published the anthology Xin Shiji zhi Lü 《新世紀之旅》Travelling to a New Century. The stories were located in the near future, the year 2020 and it was the first Taiwanese Weilai Wenti Xiaoshuo未來問題小說 fiction on future problems, one of the mainstream topics in science fiction in Taiwan. Around the same time Zhang Xiguo using the pseudonym Xing Shi醒石Awakened Stone wrote an introduction to the excellent foreign science fiction stories in Lianhe Bao 聯合報 Ally by its supplement Kehuan Xiaoshuo Jing Xuan 《科幻小說精選》Carefully Chosen Science Fiction, these were later collected into an anthology Hai d Siwang 《海的死亡》Death of the Sea which was extremely influential for both Taiwanese science fiction readers and authors. In July 1976 Zhongyang Ribao中央日報Central Daily released a story written by an Overseas Chinese living in the USA Chang Sheng bu Lao 《長生不老》Live Forever marked as kexue xiaoshuo科學小說a fiction on science. In September 1976 Central Daily published Huang Hai's science fiction novelette Yinhe Mihang Ji《銀河迷航記》Records on Drifting Off Course in the Milky Way. In November 1977 Lü Yingzhong呂應鐘established at his own expense Yuzhou Kexue 《宇宙科學》Universal Science magazine, presenting articles on E.T., new discoveries in astronomy, paranormal phenomena and science fiction. It was not only the first special platform for Taiwanese science fiction literature, but also the real beginning of UFOlogy in Taiwan. Lü Yingzhong is therefore regarded as "the godfather of Taiwanese UFOlogy". In 1978 the finest of Zhang Xiguo's fictions, the saga Xingyun Zuqu 《星雲組曲》Nebula's Suite began to be published in Ally. In July 1978 Lü Yingzhong's Universal Science organised the first symposium on science fiction in the history of Taiwanese literature. In 1979 Ally published the first Taiwanese science fiction “essay” Jiade he Diqiuren 《迦得和地球人》 Gad and Terrestrial by Wu Wangyao吳望堯, an Overseas Chinese who had returned to Taiwan from Vietnam, and also the first Taiwanese science fiction poems. The American science fiction films, e.g. Star Wars and Close Encounters of the Third Kind, etc. were shown in Taiwan and helped to encourage an increasing interest in science fiction. Zhaoming照明Illumination, Guojia國家Country and Xingji星際InterStar Publishing Houses published Taiwanese science fiction and translations of foreign science fiction in the 1970s. In 1979 Huang Hai delivered several lectures on science fiction at Danjiang University. Science fiction translations, theoretical papers on science fiction and Taiwanese science fiction in Mingri Shijie 《明日世界》A World of Tomorrow - the magazine of the

e. g. Alexandr Romanovich Belyayev's Beaier Boshi d Naodai 《德埃爾博士的腦袋》Professor Dowell's Head. 
university, were the result of a course on futurology creation at Danjiang University in the late 1970s. In August 1979 Ye Yandu 葉言都completed the initial part of the first Taiwanese catastrophic and military science fiction, the pentalogy Hai Tian Long Zhan 《海天龍戰》A War of the Ocean and Heaven Dragons. In October 1979 Li Qi's李頎 ${ }^{3}$ novel Tao Hua Yuan 《桃花源》Peach Blossom Spring - Utopia was released.

1980s: The 1980s began with the publication of the first theoretical monograph on the science fiction written by Lü Yingzhong Kehuan Wenxue 《科幻文學》Science Fiction Literature. The book is divided into two parts with the first describing the theory and history of science fiction, while the second is a handbook, a manual on how to write science fiction. This was the only theoretical work on science fiction for a long period of time, not only in Taiwan but also throughout the entire Chinese world. A bimonthly Feidie yu Kehuan 《飛碟與科幻》UFO and SF, a new platform for Taiwanese science fiction, was also established by Illumination Publishing House. It was focused on Taiwanese science fiction, theoretical works of science fiction and the science fiction arts, primarily publishing works by Huang Hai and Lü Yingzhong. Starting in September 1980 Minzu Wanbao 《民族晚報》The National Evening Paper created Kehuan Shijie Zhuanlan《科幻世界專欄》A Column on the Science Fiction World weekly. Lü Yingzhong translated the masterpiece of the science fiction star Arthur C. Clark 2001: A Space Odyssey. In the 1980s Huang Hai published his first works of children's science fiction literature. The 1980s was also a period of anthologies of foreign science fiction translation along with the publication of Taiwanese science fiction, Zhang Zhijie 張之傑, Huang Hai and Lü Yingzhong edited Zhongguo Dangdai Kehuan Xuanji 《中國當代科幻選集》An Anthology of Chinese Contemporary Science Fiction a selection of the finest foreign and Taiwanese authors over the last twenty years. In the early 1980s Taiwan Normal University organised a symposium on Zhang Xiguo's fiction Nebula's Suite. Zhang Zhijie founded Kehuan Wenxue 《科幻文學》Science Fiction Literature quarterly with an aim at promoting science fiction, only to cease after releasing only one issue. Huang Fan's 黃凡 story Ling 《零》Zero was the first Taiwanese science fiction awarded by Ally with the extremely prestigious Novelette Prize. On the eve of the 4th May Movement in 1982 Ally organised a symposium on science fiction. Zhang Xiguo began to release the first part of his science fiction trilogy Cheng 《城》City called Wu Yu Die 《五玉碟》Five Plates of Jade in China Daily. The trilogy imitates Chinese epic tradition and mythology and is an excellent portrait of China. The trilogy was also translated into English and is consequently popular as a chivalrous science fiction romance very similar to David's Wingrove famous saga Chung-kuo creating a romantic mood of history. In 1984 Zhang Xiguo in co-operation with China Times announced the first Taiwanese science fiction prize which had six sessions all together. During the first

\footnotetext{
3 also Li Xingchang李幸長
}

one the jury received fifty science fiction stories: Fan Shenghong's范盛泓Wen 《問》Question and Zhang Dachun's張大 春Shangshizhe 《傷逝者》The Man who Mourned the Loss of a Loved one were the most successful ones. In 1986 the competition changed its name to Zhang Xiguo's Science Fiction Prize. In 1986 the second part of Zhang Xiguo's trilogy City Long Cheng Fei Jiang《龍城飛將》The Flying General of Dragon City was also published. In 1987 Chen Kehua陳克華 published an epic science fiction poem Xingqiu Jishi 《星球紀 事》Chronicle of the Stars. One year later Kuling苦苓edited an anthology Zhongguo Erling'erling Nian 《中國2020年》 China 2020, collecting masterpieces of Taiwanese science fiction literature from the 1980s. The last session of Zhang Xiguo's Science Fiction Prize held in 1989 had 102 participants, among them 53 authors from Mainland China. On 2nd January 1990 Zhang Xiguo founded Huanxiang 《幻象》Mirage magazine at a tea party and announced a new science fiction literature prize. Mirage was published for three years in eight issues and was the most influential Taiwanese science fiction magazine ever. That same year Huang Fan黄凡and Lin Yaode 林燿德 compiled Kehuan Juan 《科幻卷》Science Fiction the 12th volume of Xin Shidai Xiaoshuo Da Xi 《新世代小說 大系》Mega Series on Fiction of the New Generation, collecting science fiction short stories after 1968. Huang Hai's Qiyi d Hangxing 《奇異的航行》Bizarre Sail was awarded the Hong Jianquan Children's Literature Prize, in 1984, Chang'e Cheng 《嫦娥城》A City of Chang'e the Sunjatesen Literature Prize and a year later, $\mathrm{Da} B i$ Guo Lixian Ji 《大鼻國歷險記》 Records of Adventure in Big Nose Country the National Literature Prize and Diqiu Taowang 《地球逃亡》Escape from the Earth the Oriental Children's Literature Prize ${ }^{4}$ in 1988 both, Hang Xiang Weilai 《航向未來》Sailing to the Future the Chinese Children's Literature Prize in 1989, Di San Zhi Jiao $d$ Weidao 《第三隻腳的味道》Smell of the Third Foot the Mainland - Taiwan Children's Literature Prize in 1989 as well. City of Chang'e also released as a MC record, Records on a Drift off Course in the Milky Way was adapted by Zhongguo Guangbo Gongsi中國廣播公司 the China Radio Company as a radio drama. The creators of the Records of Adventure in Big Nose Country radio adaptation were awarded the Golden Radio Prize in 1987 and Cai Shangzhi蔡尚志dedicated a chapter of his university textbook Ertong Gushi Yuanli 《兒童故事原理》Principles of Fairy Tales to Huang Hai's children's science fiction.

After: At the beginning of the 1990s the majority of the Taiwanese science fiction authors graduated from university, many of them having been experts in the natural sciences. Those who were graduates in the humanities creating science fiction prose also paid a certain amount of attention to science. As a result the science in their works is not pseudo-science, it is not a matrix of knowledge, and it is not a literature about Strangeness, Force, Chaos and Mysteries due to which science fiction is disregarded by main-stream non-scientific fiction.

\footnotetext{
${ }^{4}$ it was the first Oriental Children Literature Prize ever awarded
} 
From 18th till 24th June 1990 Zhang Xiguo's Mirage organised the Taibei Science Fiction Week. Several foreign science fiction authors attended and each day a renowned Taiwanese author gave a speech with famous science fiction films shown simultaneously. In 1991 the first World Chinese Science Fiction Art Prize was announced. Although Mainland authors received the majority of the prizes, Lin Yingshan 李英杉and Chen Qiuling's陳秋玲comic Diyu 《地獄》 Hell was also awarded. In 1992 Zhang Xiguo completed the last part of his City trilogy Yi Yumao 《一羽毛》A Feather. In 1993 Jiang Yunsheng姜云生 edited Taiwan Kehuan Xiaoshuo Daquan - Sishi Nian Ming Jia Ming Zuo Jing Xuan 《台湾科幻小说 大全一一四十年名家名作精选》A Complete Collection of Taiwanese Science Fiction - The Essential Anthology of Famous Authors' Masterpieces over the last Forty Years which was published in Mainland China. Lü Yingzhong's fiction Long Chuan Zheng Kong Ji 《龍船征空記》Records of a Dragon Boat Journey in the Universe was the first Taiwanese science fiction ever released in Mainland China by Anhui Shaoer安徽少兒Anhui Children's Publishing House. In June 1996 Central Daily organised Bai Nian lai Zhongguo Wenxue Huiyi 《百年來中國 文學會議》A Conference on Chinese Literature over the last Hundred Years with science fiction literature being one of its topics. The panel was chaired by Huang Hai while Jiang Yunsheng姜云生also part giving a speech. In February 1998 Kexue Yuekan 《科學月刊》Science Monthly published a special issue on science and science fiction and therefore created an opportunity for many Taiwanese, Mainland and Overseas science fiction authors to present their views. In May $1998 \mathrm{Ke}-$ huan Shikong科幻時空 Science Fiction's Time and Space, an internet web site containing of a science fiction literature part was launched (www.thinkerstar.com) and in February 1999 a special science fiction internet web site Ke Ke Wang科科網 Sci Sci Net was established (www.scisci.com). In the middle of 2000 the address was changed to (http://scisci.nctu.edu. tw). In April 1999 Jingyi University organised a conference on Children's Literature and Huang Hai's children's science fiction was the subject of a special discussion panel. In September 1999 Ye Lihua葉李華began to teach Kehuan Tiandi科 幻天地The Universe of Science Fiction at Shi Xin University and the Taiwanese Academy of Arts as the first course on science fiction, a part of the curriculum at universities in Taiwan. In December 1999 Haiyan海燕Petrel Publishing House in Henan published the anthology Ershi Shiji Zhongguo Kehuan Xiaoshuo Jingpin 《二十世紀中國科幻小說精品》 Excellent Works of Chinese Science Fiction in the 20th Century, also listing works by Zhang Zhijie, Huang Hai and Lü Yingzhong. At the beginning of the new millennium Ye Lihua established Kehuan Yanjiu Zhongxin科幻研究中心The Centre for Science Fiction Studies. In 2000 Zhang Xiguo held lectures on science fiction literature at Zhong Yang University. In the middle of February $2000 \mathrm{Ke} \mathrm{Ke} \mathrm{Dianzi} \mathrm{Bao \text {《科科電 }}$ 子報》Sci Sci Digital magazine was established with its primary purpose being the provision of information about the situation in science fiction. In September 2001 Lü Yingzhong organised the lecture Kehuan Xiaoshuo yu Dianying 《科幻小
說與電影》Science Fiction Literature and Films at Nan Hua University, in which 153 students enlisted and Prof. Wu Yan 吳岩released Kehuan Wenxue Gailun 《科幻文學概論》 An Introduction to Science Fiction Literature. In 2003 a major conference on science fiction studies was organised.

\section{CONCLUSION}

Summary: Although the roots of Taiwanese science fiction date back to the 1950s, the real history of the phenomenon represented by the publication of Zhang Xiaofeng's psychological science fiction Pandora began in the late 1960s. The next development in Taiwanese science fiction in the 1970s was possible thanks to the support of several newspapers and magazines, e. g. China Times, China Daily, Pure Literature, Ally, Central Daily, etc. and due to creative individualities, e. g. Huang Hai, Zhang Xiguo, Lü Yingzhong ${ }^{5}$ etc. who promoted science fiction in Taiwan and throughout the Chinese world. Papers on science fiction literature, non-Chinese first and Chinese later, established a solid foundation for new authors and readers along with the translation of foreign science fiction literature. Literary prizes as served not only as an encouragement to authors but as advertising for readers as well. Stories released in newspapers and magazines first were later published in anthologies and therefore became accessible to a wider range of readers. In the late 1970s, the first science fiction magazine appeared, the first symposiums on science fiction were organised and several lectures on science fiction were held at universities. As a result more and more publishing houses expressed an interest in science fiction. In addition, the first theoretical monograph on science fiction came about. The 1980s witnessed a deepening of the phenomena described above, more quantitative than qualitative: more authors and theorists, more stories, more books, more anthologies, more magazines, more publishing houses, more symposiums and more lectures which identified themselves in connection with science fiction literature. And, of course, more readers whose attention was caught by increasing numbers of prestigious prizes for science fiction authors, by the creation of the first Taiwanese science fiction prize, by the establishment of the first special science fiction magazine and by the introduction of science fiction literature into other media than paper. The 1990s were marked by the beginning of co-operation with Mainland China and by the rapid rise of the Internet.

A Comparison: A comparison of American and Taiwanese science fiction is not an easy challenge. Firstly, the history of

\footnotetext{
${ }^{5}$ Lü Yingzhong in his article "A Concise History of Taiwanese Science Fiction Literature" also mentions the contribution of Ye Lihua, Zhang Dachun, Zhang Zhijie, Ye Yandu葉言都, Zheng Wenhao鄭 文豪, Li Jing李敬, Xu Xiangjun許薌君, Chen Kehua, Li He李赫and two theorists of $A$ World of Tomorrow magazine Wang Changhong 王長洪and Peng Guangyang彭廣揚
} 
American science fiction began in 1923, Taiwanese in 1968. This not only involves a difference of two science fiction histories amounting to 45 years, almost half a century, but also a major difference in terms of the periods in which they were created: the between-the-wars period and the middle of the Cold War. The tradition of American science fiction emerged from special science fiction magazines. The first science fiction magazine in Taiwan was established in the 1990s, more than twenty years after the publication of the first science fiction story. This means that at the beginning paperbacks were the main "media" for the expansion of science fiction in Taiwan, not magazines. In contrast, paperbacks were a very important media of spreading science fiction in the USA when science fiction was finally adopted in Taiwan. As regards the publication of science fiction, a slight difference also exists in terms of the concept in Taiwan and the USA. While in Taiwan there is a tradition of publishing a story in a newspaper or a magazine first and then later as a book, the publication of a story in the USA does not necessarily need to follow this procedure, on the contrary magazines and books markets are quite separate from each other. The roots of science fiction in the USA and Taiwan are, of course, also very different: American science fiction evolved from the tradition of Jules Verne and Herbert George Wells's technical science fiction creating a new tradition in the 1950s, which was followed not only by Taiwan, but also by the entire Western world, with the exception of Great Britain. American science fiction of the 1950s is adventurous, employing science fiction motifs as a decoration. Pseudo-science, also extremely popular in American science fiction of the 1950s is, by the way, reflected in the works of Zhao Zifan mentioned above. What is strikingly different from the situation in the USA is an absence of fan activities in Taiwan. This probably had something to do with what kind of reader consumes science fiction in the USA and Taiwan. The social structure of the recipients in the USA is heterogeneous while it is mainly students who consume science fiction in Taiwan. It is also difficult to find the "spiritual ghetto" mentioned in the history of American science fiction in the 1950s in Taiwan. The majority of the science fiction authors in Taiwan are not only science fiction writers, Zhang Xiguo and Huang Hai being excellent examples. In contrast, science fiction authors in the USA seldom write non-science fiction stories. Also the time of the Golden Age of science fiction in the USA and Taiwan is consequently different, it being a eight year period from 1938 until 1945 in the USA, and the 1980s in Taiwan. The hyperbole that was so common in the 1950s in the USA was not possible in Taiwanese science fiction at all. Firstly, it was the time of Martial Law in Taiwan; secondly, hyperbole is not a typical expressive mood of any Chinese science fiction. The only example of satirical science fiction in Chinese is Lao She's City of Cats, I would argue. I am of the opinion that the British New Wave of the 1960s did not influence Taiwanese science fiction as it did American science fiction by emphasising the importance of human individuality and the demolishing of taboos in the USA. Again, there is not a particularly rich soil for this in Taiwan, influenced by the collectivism of Chinese culture with its taboos, which have a history of not merely hundreds but thousands of years. What Taiwan was touched by was the "li-fi" movement in the 1970 s in contrast to the cyberpunk of the 1980s which failed to impact Taiwan. As regards genre, Taiwanese science fiction is not as rich as American is: alternative history, time travel, sex and lost worlds are rarely found in Taiwanese science fiction. It is instead more sociological, closer to soft science fiction.

American science fiction never had to come to terms with the problem of its identity, while Taiwanese did, as science fiction was an alien "hostile" genre for Taiwanese literature. Firstly, Taiwanese science fiction had to accept concepts which were elaborated by an extremely different Western culture and confront the Western understanding of fantastic elements with the Chinese one. This is the reason why the first stories by Zhang Xiaofeng and Zhang Xiguo were so "Christian". Why would a Chinese author rely on a Western tradition? The answer is very simple: Mr. Science Fiction came from the West thus his appearance and his substance is a Western one. Secondly, Taiwanese science fiction had to find an identity, am I Taiwanese or Chinese? The difference between China and Taiwan is expressed in many areas and although science fiction should therefore be no exception, there is one. I believe it is very difficult to express one's identity when the cultural traditions of China and Taiwan are almost the same and the literary language is the same. The tertiary, western science fiction has its own language, therefore Taiwanese science fiction has had to create its own language. Zhang Xiguo often employs the language of The Romance of the Three Kingdoms and All Men Are Brothers, Chinese chivalry novels in his science fiction stories. It is more important for science fiction to identify itself in comparison with her Western older brother, I presume. Who, which reader would be interested in Taiwanese science fiction if it would not bring something new in comparison with translations of foreign science fiction? It is a difficult challenge, isn't it? How to match up with more experienced foreign science fiction? The path for Taiwanese science fiction has been to mix traditional literature with science fiction, without, however, merely creating a science fiction background for Chinese stories. It is more about putting new blood into old stories, not into their appearance but into their substance. Western science fiction has its own language, thus it should be interpreted in light of this fact. A translation would not attract a Taiwanese reader, he would not have been familiar with it: science fiction was strange for him not only as regards its content but also formally. Therefore the replacement of that strange language would be more appropriate which is also why Zhang Xiguo suggested using the language of Chinese chivalry novels. It is an excellent idea to compensate for the Western science fiction language with a Chinese one. The success of these books proves him right. He also achieved it by adopting Chinese mythology and history into his stories, something which the reader felt familiar with and could identify with. Common narratives merely describe relationships between people and are limited as re- 
gards space. Science fiction is about the relationship between humanity and the universe and prophesies about the future. I also believe that Zhang Xiguo's "homesickness" and Chinese "friendship" can be trapped in his works and have already became a part of the Chinese universe. The relationship between people in Zhang Xiguo's works, especially the emotional one is somehow closer to the Chinese one than to the Western. Zhang Xiguo is also not describing the Chinese society as different from today, he does not express his views of it but instead only affirms societal characteristics. The last question is, could this be of interest to a reader from abroad?

The twenty years of development of Taiwanese science fiction was retarded in the early 1990s by the boom in science fiction cinema. Its history is almost complete. Literary prizes have been awarded to the old stars of Taiwanese science fiction. One can only and rarely purchase old books and anthologies in book stores; translations prevail. Evaluations by theorists, lectures, courses and symposiums on science fiction are common. Although it is the next step of decadence, Taiwan is not an exceptional example. The situation for science fiction literature is critical globally. The crisis is related to the decline of literature on a global scale where the average person does not have enough patience to read a book. How it is possible that so many people are touched by the nonsense of knighterrant fiction and love stories are read by so many, but the description of the future of humanity fails to touch anyone? Only Taiwanese university students are interested. There are courses on science fiction in the curriculum of natural science faculties and courses on how to write science fiction in the humanities. Academic discussion, symposiums and conferences are extremely popular. Taiwanese science fiction is a definite phenomenon and can be analysed and described. It is the main purpose of this paper.

\section{REFERENCES}

Huang Hai带海 (2007): Taiwan Kehuan Wenxue Xinhuo Lu (1956-2005) 《臺灣科幻文學薪火錄》[On the Torch of Taiwanese Science Fiction Literature]. Taibei: Wu Nan Tushu Chuban Gufen Youxian Gongsi.

Jiang Yunsheng姜云生 (ed. 1993): Taiwan Kehuan Xiaoshuo Daquan - Sishi Nian Ming Jia Ming Zuo Jing Xuan 《台湾科幻小说大全一一四十年名 家名作精选》[A Complete Collection of Taiwanese Science Fiction - Essential Anthology of Famous Authors' Masterpieces within the Last Forty Years]. Place unlisted: Fujian Shaonian Ertong Chubanshe.

Lü Yingzhong呂應鐘and Wu Yan曲岩 (2001): Kehuan Wenxue Gailun 《科幻文學概論》[An Introduction to Science Fiction Literature]. Taibei: Wu Nan Tushu Chuban Gongsi.

Neff, Ondřej (1986): Všechno je jinak - kapitoly o světové science fiction [Everything's Different - Chapters about World Science Fiction]. Praha: Albatros, $412 \mathrm{p}$.

Neff, Ondřej and Jaroslav Olša, Jr. (1995): Encyklopedie literatury science fiction [Encyclopaedia of Science Fiction Literature]. Praha, Jinočany: AFSF, $\mathrm{H} \& \mathrm{H}$.

Xiang Hongquan向鴻全(ed. 2003): Taiwan Kehuan Xiaoshuo Xuan 《臺灣 科幻小説選》[Anthology of Taiwanese Science Fiction Literature]. Taibei: Er Yu Wenhua.

\section{INTERNET}

2008-04-06 Huang Hai黃海Ye Lihua葉李華and Lü Yingzhong呂應鐘 (2008): “Taiwan Kehuan Wushi Nian Nianbiao”台灣科幻50年年表 [Chronological Table of Taiwanese Science Fiction] <www.thinkerstar. com/WSLF/NHU/sf50tw.htm>

2008-04-06 Jiang Yunsheng姜云生 (1993): “Taiwan Kehuan Xiaoshuo Fazhan Gaikuang” 台湾科幻小说发展概况一一《台湾科幻小说大 全》序 [A Survey of Taiwanese Science Fiction Development - Postface to A Complete Collection of Taiwanese Science Fiction] <http://bbs.flyine. net/thread-67711-1-1.html>

2008-04-06 Lin Jianqun林健群 (2006): “Taiwan Zhuliu Kehuan Pingxi” 臺灣主流科幻評析 [Critical Analysis of Mainstreams in Taiwanese Science Fiction] <http://danjalin.blogspot.com/2007/10/2006-1. html > <http://danjalin.blogspot.com/2007/10/2006-2.html > <http:// danjalin.blogspot.com/2007/10/2006-3.html $><$ http://danjalin. blogspot.com/2007/10/2006-4.html $><$ http://danjalin.blogspot. com/2007/11/2006-55.html>

2008-04-06 Lü Jinbo呂金駮1 (1996): “Taiwan Kehuan Wenxue Jian Shi” 臺灣科幻文學簡史 [Concise History of Taiwanese Science Fiction Literature] <www.thinkerstar.com/lu/sci-fi/sf-tw01.html>

1 also Lü Yingzhong呂應鐘

\section{AUTHOR}

Uher, David (born June 29, 1970, Frýdek-Místek), originally trained as a sinologist and holds a MA from Charles University in Prague. He has a Ph.D in Chinese Philology from the Department of Chinese Language, Nanjing University (P. R. China). He was appointed Director of the Department of Asian Studies after spending almost a decade in the Chinese Philology in the Faculty of Arts at Palacký University in Olomouc. He has published widely, mainly in the fields of Chinese grammatology and the history of Chinese linguistics. $\mathrm{He}$ is a co-author of An Introduction to the Chinese Language [Úvod do studia hovorové ćinštiny] $(1997,2001)$, co-operated on A Colloquial Chinese in Sentence Examples [Hovorová čínština $v$ př́ikladech] (O. Švarný 1998), The Learning Dictionary of Spoken Chinese [Učebni slovník jazyka čínského] (O. Švarný 1998-2000), Chinese Characters Textbook [Učebnice čínských znaků] (Ondřej Kučera 2005), Jewellery of Chinese Literature [Klenoty činské literatury] (Lucie Olivová 2006) and encyclopaedia Who is Who in the History of Czech Linguistics [Kdo je kdo v dějinách české lingvistiky] (Jiří Černý, Jan Holeš 2008). Bibliography in selection: (2000): "Gu Yindu, gu Xila yu Zhongguo gudai yuyanxue bijiao" [A comparation of ancient linguistics in Old India, Greece and China], Gu Hanyu Yanjiu [Research on Classical Chinese], 2, 19-23. (2002): "Xu Shen: Doslov k Výkladu významu základních a vysvětlení struktury složených znaků [Xu Shen: Poscript to The Meaning Explanation of Primary Characters and Structure Analysis of Secondary Characters]", Studia Orientalia Slovaca, 1, 43-54. (2005a): "Six Cathegories of Chinese Characters", in Pecha, Lukáš (ed.): Orientalia Antiqua Nova, V, Plzeň, 125-137. (2005b): "Xu Shen a počátky čínské gramatologie [Xu Shen and the beginnings of Chinese grammatology]", Studia Orientalia Slovaca, 4, 247262. (2007): “Gramatolog Duan Yucai段玉裁 (1735-1815) [Grammatologist Duan Yucai (1735-1815)]" Studia Orientalia Slovaca 6, 203-224, with Inoue, Kazuyuki (2008a): "Classification of the most frequent verbs in Sima Qian's Records of Historian (Biographies)", Social System Review, 2, 1-14. (2008b): "Determinativ božský ve Výkladu významu základních a vysvětlení struktury složených znaků [Determinative Celestial in The Meaning Explanation of Primary 
Characters and Structure Analysis of Secondary Characters]", Studia Orientalia Slovaca, 7, 97-109. (2008c) "Postava učitele orientalizovaná vědecko-fantastickými filmy" [Character of the Teacher Orientalised by Sci-fi Movies], in Pecha, Lukáš (ed.): Orientalia Antiqua Nova, VIII, Plzeň: Adela, 412-428. (2010) "Zvířecí determinativy v čínském písmu [Animal Determinatives]", in Olivová, Lucie (ed.): Zvírecí mýty a mýtická zvírata. Praha: Academia 2010, 106-126.

Contact: Mgr. David Uher, Ph.D., Katedra asijských studií Filozofické fakulty Univerzity Palackého v Olomouci, Kř́žkovského 8, 77180 Olomouc, e-mail: david.uher@upol.cz. 